\title{
A perda e a recuperación do voto en Cortes do reino de Galicia
}

Manuel $\mathrm{M}^{\mathrm{a}}$ de Artaza Montero

Universidade de Santiago de Compostela 
Sendo Galiza o reino máis antiguo de Hespaña, negóuselle capacidade para asistir ás Cortes, i esta é unha ofensa imperdoable; pero máis ofensa foi a de someternos a Zamora - unha cibdade fundada por galegos, pero arredada xa do noso reino e diferenciada etnicamente de nós.

Alfonso Daniel R. Castelao, Sempre en Galiza

\section{- A perda do voto}

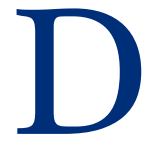

entro da prolongada e intensa crise baixomedieval que viviu Galicia, probablemente a perda do voto nas Cortes de Castela en tempos de Xoán II (1406-1454) marque o nadir da súa historia política. De feito, «recuperar» o voto converteuse nun obxectivo prioritario das elites dirixentes galegas ata que o acadaron en 1623, reinando Filipe IV. Por outra banda, esta ferida foi, sen dúbida, aínda maior, porque Zamora, a cidade que pasou a falar por Galicia naquela asemblea, o fixo co título de cabeza do reino. O peso político e o prestixio do territorio galego e dos seus habitantes non puideron, pois, caer máis baixo.

En calquera caso, ata hoxe non temos datos certos do motivo de Xoán II para permitir semellante perda, porque o dereito de asistencia das cidades ás Cortes era unha titularidade exclusiva do rei (Carretero Zamora 1988: 3) e ata finais do século XIV houbo presenza nelas de procuradores dos núcleos urbanos galegos. Así, segundo un testemuño do arquiveiro de Simancas de 1573 solicitado con motivo da demanda de devolución do voto, consta que un procurador coruñés chamado Periáñez (ou Pedro Yáñez) ${ }^{\mathbf{1}}$ asistiu ás de 1396, convocadas por Henrique III (1390-1406) (Fernández Vega 1980: 70-71). Non obstante, en 1419, nas reunidas en Madrid co gallo da asunción do goberno por Xoán II tras a desaparición dos seus titores e rexentes, só atopamos os delegados de dezasete cidades e vilas (Burgos, León, Zamora, Toro, Salamanca, Ávila, Segovia, Soria e Valladolid na meseta norte; Toledo, Cuenca, Guadalaxara, Madrid e Murcia

1. Nun memorial redactado por Ares González, secretario da Real Audiencia de Galicia, no cal se fai a historia do voto e que foi dirixido ao rei Filipe II polo conde de Lemos e o cardeal-arcebispo de Sevilla don Rodrigo de Castro, este é o nome do vogal coruñés. A transcrición de «La razón que Ares González [...] ha hallado en historias antiguas y en los archivos de Simancas y en otras partes, para lo tocante al voto del Reino de Galicia» (1585), en Fernández Duro (1883: 32 e 44-52). 
no sur; Sevilla, Córdoba e Xaén en Andalucía). As mesmas que, agás excepcións, aparecerán nas posteriores xuntanzas ata 1498, cando Granada, conquistada en 1492, pasou por vontade dos Reis Católicos a ser a número dezaoito. Esta cifra permaneceu inalterada ata o retorno dos representantes de Galicia en 1623; por conseguinte, logo da última participación de nobres e cregos nas Cortes Xerais reunidas en 1538 por Carlos I, tal e como apuntaba a tendencia consolidada no século XV, o Parlamento de Castela converteuse nunha xuntanza do rei cun número limitado de cidades que tamén falaban por outros «enormes» territorios da coroa que non tiñan presenza nel. Sirva de exemplo o sucedido con Asturias, representada por León; boa parte da actual Cantabria, representada por Burgos, ou Estremadura, representada por Salamanca ${ }^{2}$. Deste xeito, as Cortes non foron, como noutras partes de España (Aragón, Cataluña, Valencia ou Navarra) e de Europa, unha asemblea interestamental que, en 72 función das concepcións político-xurídicas do Antigo Réxime, encarnase con propiedade o reino (communitas regni) (Carretero Zamora 1988: 10-14 e 2001: 263; Dios 1991: 187; Fernández Albaladejo 1992: 256, 331-332), cousa que denunciou o xesuíta Juan de Mariana a finais do século xvi nun famoso libro dedicado a Filipe III (De rege et regis institutione, 1599: 101). De aí a súa debilidade para se converter nun contrapeso eficaz do poder real e para participar na elaboración de leis, normas exclusivamente rexias. Polo tanto, no caso castelán, foron o dereito e os tribunais e consellos da coroa os que verdadeiramente limitaron a autoridade dos monarcas (Fernández Albaladejo 1992: 318-321). Con todo, non debemos subestimar o papel das Cortes, pois, sen afondarmos nel, grazas ao seu rol fiscal, do que axiña falaremos, como intermediarias entre o rei e as oligarquías urbanas, influíron na política de Castela e mesmo da Monarquía Hispánica ata entrado o século XVII. Por iso, con independencia dos beneficios económicos, premios e cargos outorgados polo rei aos procuradores, para os dirixentes galegos a recuperación do voto non foi simplemente unha cuestión de honor, malia que na sociedade do Antigo Réxime era un aspecto fundamental.

Volvendo ao fío da nosa historia, debemos dicir que, á marxe de que non coñezamos os motivos de Xoán II, a ausencia dos procuradores dos concellos

\footnotetext{
2. Na práctica, pois, a maior parte das terras da coroa de Castela, fosen de reguengo ou señoriais, non participaban nas tomas de decisión das Cortes. Unha listaxe deses «enormes territorios» sen «presenza efectiva nos asuntos tratados en Cortes» a comezos do século XVI, en Carretero Zamora (1988: 17). O señorío de Biscaia e mais as provincias de Guipúscoa e Araba, por mor da súa peculiar incorporación á coroa, gozaron dun réxime político-fiscal que facía innecesaria a súa presenza no Parlamento castelán. Tampouco pagaban os servizos. Unha panorámica dos territorios sen representación en Cortes, en Baró Pazos (ed.) (2017).
} 
galegos en 1419 creou un problema xurídico: o reino de Galicia non prestara o xuramento de fidelidade ao novo soberano ou ao príncipe herdeiro segundo era preceptivo. Así as cousas, nas Cortes convocadas en 1424 chamouse a un reducido número de cidades (doce) para xurar a infanta Leonor - unha irregularidade en opinión de Manuel Colmeiro (1883: 21)-. Pero os seus vogais, sumados a nobres e prelados, remataron xurando en 1425, en Valladolid, o infante don Henrique (Henrique IV cando accedeu ao trono), nado no mes de xaneiro dese ano. Entón déuselle unha solución á falla de xura do reino ao seu pai: a cidade de Zamora xurou o príncipe por si e por Galicia. Con esta innovación, Zamora melloraba o seu posto na xerarquía da asemblea, situándose á dereita de Burgos. E, claro, o rexedor zamorano Juan Alfonso Huete pediu copia da acta para consolidar o logro, fin que non conseguiu, segundo amosa a orde cidadá de anos posteriores. Tendo en conta a importancia e a escasa difusión do documento, transcrito por César Olivera Serrano, paga a pena ler esta pasaxe:

E por quanto los procuradores de la çibdad de Çamora acostumbravan a sentarse juntos con los de Leon a la mano diestra de la dicha çibdad de Burgos, por la dicha çibdad de Çamora ser cabeça de Galisia, el dicho Condestable hordenó e mandó a los procuradores de Çamora se asentasen junto con los procuradores de Burgos a la mano diestra, e Burgos en el lugar asignado para los de Leon. $\mathrm{E}$ los dichos procuradores fisyeron e cumplieronlo asi, e juntos con los procuradores de Toledo se asentaron los procuradores de Sevilla, e luego los de Cordova e çerca dellos los de Murçia e a par de Murçia los de Jahen. En el qual dicho abto e solegnydad a la dicha çibdad de Çamora fue guardada su prerrogativa e preheminençia asi en el asentar como en el fablar como en el jurar e besar de la mano al dicho Prinçipe de Asturias, e de todo esto en como pasó los dichos procuradores de la dicha çibdad de Çamora pidieronlo por testimonio signado a los presentes notarios e secretarios del dicho sennor Rey, que ende estavan de yuso escriptos. E dieron ende este en la manera e anno susodicho. (Olivera Serrano 1986: 178) 
Mais o remedio non foi tal, porque a partir de 1429 os galegos deixaron de contribuír ás axudas económicas extraordinarias ou "servizos» das Cortes (os «pedidos» e as «monedas» ${ }^{3}$ ), segundo denuncian as de Palencia en $1431^{4}$. A razón, en sintonía co dereito e os tratadistas do seu tempo, era que os servizos foran aprobados sen consentimento dos seus voceiros. A mesma alegación dos colonos norteamericanos - «no taxation without representation»- para rexeitar os impostos establecidos polo Parlamento británico despois da guerra dos Sete Anos (1756-1763). No reino galaico non se chegou a desencadear ningunha revolución secesionista, pero a utilización deste $\operatorname{argumento}^{5}$ e a resistencia fronte ao pago dos subsidios votados en Cortes ata o reinado de Isabel I e Fernando V de Trastámara foi notable. Teñamos en conta que as cantidades repartidas polos pedidos eran das máis elevadas de Castela, «superando habitualmente un $10 \%$ del total» entre 1440-1469. E que as cotas asignadas neses anos ao arcebispado 74 de Santiago e a súa sé sufragánea de Tui fixeron que na xerarquía contributiva da coroa chegase a ser o terceiro partido fiscal (Triano 2018: 98-103).

Agora ben, cómpre non esquecer que esta rebeldía tributaria é paralela á da satisfacción das rendas reais ordinarias (alcabalas, décimos do mar e alfolíns), afectadas pola crise da actividade económica e comercial galega dos tres primeiros cuartos do século XV, mais, en especial, pola actitude dos señores. Lembremos que a Galicia do Antigo Réxime foi un territorio onde as xurisdicións señoriais laicas e eclesiásticas (por riba dun $80 \%$ da poboación vivía nelas) predominaron amplamente sobre o reguengo (Saavedra 2007: 185-214). Nos señoríos, os seus titulares gobernaban, xulgaban e percibían rendas, cousa que atrancou o exercicio da autoridade e da fiscalidade do rei ao longo do Catrocentos (por exemplo, a usurpación das alcabalas foi un dos motivos de conflito cos soberanos, aínda que tamén foi frecuente a apropiación doutros impostos como consecuencia de dádivas da coroa). Ademais, a crise da autoridade rexia

3. Respecto das moedas, parece ser que Galicia estaba exenta (Triano 2018: 103).

4. Cortes de los antiguos reinos de León y Castilla: publicadas por la Real Academia de la Historia, Madrid, M. Rivadeneyra, 1866, t. III, petición 14, p. 102. Tamén os procuradores denuncian a rebeldía de Asturias, que persistirá, como no caso galego, ata finais do século XV.

5. A referencia máis coñecida (Olivera 1989: 317; Rubio 2016: 235) é a contestación do ano 1465 dada polo concello ourensán a un interrogatorio dos ministros de Henrique IV sobre a situación do reino con propostas para unha reforma deste: «... para lo qual disen que pues non fueron llamados nin por ellos otorgados que por esta rason no son ni seran obligados de pagar lo que los otros procuradores de los otros vuestros regnos que para ello fueron llamados lançaron e repartieron en el dicho vuestro regno [de Galicia]». O texto íntegro do cal tomamos esta pasaxe foi publicado por García Oro (1977: 245-248, esp. 247). 
no conxunto da coroa de Castela facilitouno. Finalmente, tampouco debemos esquecer como algúns monarcas lles outorgaron aos señores exencións no pago das axudas extraordinarias concedidas polas Cortes, e iso complicou a súa recadación (Rubio Martínez 2016: 101-102 e 222-223).

Pois ben, vista a negativa ao pago dos servizos, probablemente incitada no seu beneficio político polo adiantado de Galicia Diego Sarmiento, quen foi detido por orde do rei, Xoán II cambiou de táctica. Primeiro, en 1431, mandou ás cidades e vilas o envío de procuradores a Ponferrada para intentar rematar coa indisciplina fiscal, pero non sabemos en que parou ese congreso nin mesmo se chegou a efectuarse. Logo, en 1432, buscou outro remedio: a xura do príncipe de Asturias, feita por Zamora en 1425, polos representantes dos concellos galegos. O curioso foi que o monarca decidiu levar a cabo o acto na devandita cidade do Douro. A xuízo de César Olivera Serrano, a medida non pretendía humillar a Galicia, senón demostrar a falla de valor xurídico do acto realizado polos procuradores zamoranos e recoñecer a rebeldía para acabar con ela (Olivera 1989: 317-318). Porén, a súa alteza fracasou de novo: Zamora seguiu intitulándose cabeza do reino de Galicia e as queixas das Cortes contra os impagamentos continuaron (Madrid, 1435; Valladolid, 1442).

De todas as maneiras, sabemos que os súbditos galegos non deixaron de satisfacer totalmente os «pedidos»: a documentación facendística conservada no Arquivo de Simancas amosa o cobro de diversas cantidades na década de 1440, mentres que, polo que atinxe a Zamora, semella que a prerrogativa de ser cabeza de Galicia nos xuramentos de Cortes non lle deu o mesmo recoñecemento no plano da xestión dos servizos (Olivera 1989: 318; Rubio 2016: 233) ${ }^{\mathbf{6}}$.

Xa nos últimos anos do convulso reinado de Xoán II, persisten as novas sobre a rebelión contra as axudas das Cortes, se ben nas de Valladolid de 1451 os procuradores observaron, por unha banda, que o reino galego gozaba do privilexio de non pagar «monedas» e, por outra, que a forte emigración a Portugal estaba detrás do contencioso. Un contencioso que estivo a piques de solucionarse coa asunción do cetro por Henrique IV (1454-1474). En efecto, nunha conxuntura crítica para o poder da coroa (sen diñeiro e ameazada polos grandes nobres, que chegarán a proclamar rei o seu medio irmán Alfonso na chamada farsa de Ávila o ano 1465), Henrique cita en 1464, en Madrid, uns procuradores de Betanzos (cidade reguenga), ocasión que aproveitan os betanceiros para pedir

6. Así, despois da concesión real aos procuradores para que nomeasen os «recaudadores mayores» de pedidos e moedas en 1445, os de Zamora limítanse a designar os do bispado de Ourense. 
a volta daqueles representantes do reino que, din eles, «agora e antiguamente» participaran nas Cortes: dous de Santiago, dous de Ourense, dous de Lugo e dous de Betanzos; "y no siendo llamados los dichos procuradores por vuestras cartas, quel dicho Reino de Galicia no sea obligado á pagar pedido de servicio ni otra cosa alguna que sobre el dicho Reino fueren lanzados y repartidos». O monarca acepta, aínda que daquela as cidades e vilas de señorío -Santiago, Ourense e Lugo cun bispo por señor- non tiñan xa dereito á representación na asemblea (Lorenzana 2014: 133; Martín 1999: 87; Piskorski 1930: 41-42), pero a graza non sería de balde: os legados betanceiros propoñen aboar dous contos de marabedís polas débedas do reino contraídas entre 1428 e 1452 reinando o seu pai, máis outra suma que ignoramos polos impagamentos que abranguían dende 1452 ata finais de 1463. A cambio, deberíase dar «fin e quito» de todo o reclamado por "pedidos» ou «monedas si las ende hubo en el dicho Reino, sin 76 les llevar por el tal fin e quito cosa alguna». Henrique IV tamén o consentiu (Fernández Duro 1883: 45-47). No entanto, o pacto non callou. Vexamos.

Como cabía esperar, dada a imposibilidade da presenza de Santiago, Lugo e Ourense, nas Cortes de 1465 reunidas en Salamanca atopamos outorgando un servizo a Juan Blanco, «procurador de la villa de Betanços, del Reyno de Galisia», quen gañou logo certa fama como capitán dos irmandiños (Olivera Serrano 1986: 296). Despois, xa ningún outro representante galego asistiu aos encontros da asemblea pese ao privilexio dado polo rei Henrique «á la dicha ciudad de Betanzos, para que cada y cuando por él ó por los reyes sus subcesores fuesen celebradas Córtes, y para ellas ó para cualesquier autos hubiesen de ser llamados los procuradores destos Reinos, que en tales casos e tiempos asimismo lo fuesen los procuradores de la dicha ciudad de Betanzos, por servicios señalados de la ciudad» ${ }^{7}$. Servizos sinalados que, sen dúbida, tamén tiveron que ver coa elevación de Betanzos de vila a cidade en 1465 polo mesmo monarca ${ }^{8}$ (un dato importante na conformación da xerarquía urbana galega, baseada na suposta antigüidade das poboacións) (Artaza 2011).

O medievalista César Olivera Serrano sostén que a causa de Henrique IV para devolver o voto ten que ver cun plan de reforma das Cortes baseado nunha identificación entre elas e as Irmandades, institución nada na Baixa

7. «La ciudad tiene este previllegio y está simple», afirma o secretario da Real Audiencia de Galicia, Ares González, quen foi tamén procurador do reino na corte, na súa memoria sobre o voto transcrita por Fernández Duro (1883: 44-52, 47).

8. O título de cidade e o dereito de asistencia ás Cortes outorgados polo rei Henrique, en Vales Villamarín (2006: 1053-1058). 
Idade Media para a defensa mancomunada dos intereses cidadáns e, sobre todo, dende que prosperaron no primeiro terzo do século XIV, para garantir a xustiza e a orde contra os abusos dos poderosos. Entón, dado que os gravames da coroa e as axudas extraordinarias do reino non chegaban á bolsa do rei pola anarquía vixente, semella que o atribulado Henrique pensou que coa cooperación das Irmandades e as súas milicias podería solucionar o problema. Por iso as multiplicou, as fortaleceu coa capacidade de interviren nos delitos contra a recadación e decidiu dotar de voto en Cortes algúns núcleos urbanos con peso nelas, como Betanzos. De aí que Juan Blanco, enviado á corte pola irmandade da Coruña, Ferrol e Betanzos para obter a carta fundacional da Irmandade galega, rematase participando no outorgamento de 1465 (Olivera 1986: 102-105 e 111-113, e 1989: 320-321).

Descoñecemos a opinión das outras cidades e vilas galegas sobre a presenza de Blanco nas Cortes de 1465 e sobre o privilexio betanceiro de enviar procuradores a estas sempre que se xuntasen (probablemente negativa). Mais, como vimos hai un momento, a recuperación do voto foi efémera. Tampouco axudaron a mantelo o enfrontamento civil entre Henrique e Afonso e a gran guerra irmandiña dos anos 1467-69 en Galicia, a revolta antifeudal máis importante do Baixo Medievo na coroa de Castela, na que, por certo, morreu o procurador Juan Blanco. En calquera caso, o feble rei Henrique non só abandonou os irmandiños e pactou cos aristócratas e o bispo Fonseca, que retornaron vitoriosos en 1469 logo de escapar ás forzas "populares»: tamén se pregou ao parecer das cidades que viñan acaparando as Cortes, porque as reunidas na vila de Ocaña no mesmo ano sesenta e nove esixiron con firmeza a non-ampliación do número dos seus membros. En palabras de Olivera Serrano, «quedó así reafirmado el carácter exclusivo de la representación, que se define como privilegio inalienable». E, nestas circunstancias tan adversas, nin Betanzos nin os outros núcleos urbanos do antigo reino tentaron rachar ese monopolio (Olivera 1989: 322). 


\section{- A recuperación do voto}

\section{A Santa Irmandade e a fin provisoria dos servizos de Cortes}

Xa que logo, non houbo procuradores galegos nas últimas Cortes do reinado de Henrique IV (Ocaña, 1469; Segovia, 1471, e Santa María de Nieva, 1474) e, así, as de Ocaña, que nos informan do fracaso do servizo aprobado en 1465 en Salamanca, suplican ao rei que Galicia pague a súa parte da cantidade outorgada por elas ese ano sesenta e nove (Olivera 1989: 135 e 146). A seguinte queixa da asemblea atopámola nas Cortes de Madrigal de 1476, reunidas por Fernando e Isabel durante un respiro na súa loita polo trono coa princesa Xoana (1474-1479) ${ }^{9}$. Os Reis aceptan o envío de comisionados para recadar «dichos pedidos»; porén, paradoxalmente, na repartición do servizo de Madrigal, o 78 último e o máis cuantioso do século xv, di Carretero (1988: 77), non figuran Galicia, Asturias nin a meirindade de Allendebro. En calquera caso, Rubio Martínez demostra que os peiteiros galegos si que o pagaron, aínda que opuxeron resistencia e non entregaron as cantidades sinaladas (2016: 243) ${ }^{\mathbf{1 0}}$. Mais, con independencia do fracaso xeral deste subsidio extraordinario para o fisco do que fala Carretero, o problema do sistema de Cortes eran as súas limitacións. Tratábase dun mecanismo lento para obter axudas urxentes, paralizado, pouco controlable, viciado por moitos abusos e, o peor, incapaz de proporcionar os ingresos necesarios para levar a cabo o ambicioso programa político da nova monarquía de Castela, que, como en Francia ou en Inglaterra, xurdiu tras un conflito sucesorio e a imposición duns reis autoritarios sobre os bandos aristocráticos. Por conseguinte, en 1478 os reis promoveron un plan a fin de acabar con estas trabas e non depender das Cortes valéndose da Santa Irmandade, reorganizada no ano 1476: todas aquelas cidades e vilas que ingresasen na Irmandade antes do día de San Xoán de 1479 e pagasen o tributo esixido para mantela veríanse libres dos servizos, e tamén de préstamos obrigatorios e outros impostos. Este sistema fiscal, inicialmente previsto para tres anos, foi un éxito e continuou ata finais de século. E, no caso de Galicia, unha vez restaurada a Irmandade en 1480, acabou coa insubmisión fiscal aos pedidos.

9. Cortes de los antiguos reinos de León y Castilla, IV, 79, petición 20.

10. Os monarcas enviaron a Galicia para facer a cobranza do pedido de 1476 o tesoureiro Fernando Mazuelo. Mazuelo debía indagar tamén a contía da débeda dos tributos ordinarios e extraordinarios do período 1453-1477. 
Con todo, a organización irmandiña de 1480, na súa función recadadora, debeu agardar á restauración da xustiza e da paz que trouxeron dous axentes reais nomeados ese mesmo ano: don Fernando de Acuña, gobernador e xustiza maior do reino, e o licenciado García López de Chinchilla, letrado do Consello Real, que o acompañaba en calidade de alcalde maior. Estes ministros, dotados de moi amplos poderes e co apoio dunha forza armada (na cal tamén participaron milicianos irmandiños), conseguirían someter os violentos señores feudais e restablecer a xustiza e a paz nun ano e medio. Entón, pese á resistencia inicial, a Irmandade quedou instaurada plenamente. De feito, os opositores chegaran a ofertar en 1477 unha elevada suma para impedir a volta da temida institución (500 000 marabedís), a entrega de castelos en depósito e a promesa de velar pola paz e a orde que eles mesmos viñan infrinxindo. Ora ben, tampouco debemos esquecer o apoio do arcebispo Alonso Fonseca (cabeza do partido isabelino na loita sucesoria) e do conde de Lemos, xunto con Diego de Andrade, para implantar a estrutura irmandiña (Fernández Vega 1982: I, 106-108; García Oro 1987: I, 331-333; Ladero 2005: 167-170; Saavedra 2007: 27-28).

Sen entrar no aínda polémico tema da «doma de Galicia» polos Reis Católicos e os seus representantes (Pardo de Guevara 2006: 438-441), é evidente que a autoridade real se fixo efectiva no reino na década de 1480. A paz, como noutros territorios de Castela, chegou coas enérxicas medidas reais de forza contra os nobres, sempre inclinados á rapina e a loitar entre eles; pero tamén a xustiza e a autoridade da coroa só chegaron a ser efectivas coa cooperación e o compromiso dos mesmos señores galegos, que, insistimos, controlaban a maior parte do territorio. Neste senso, os comisarios do rei que debían organizar as tropas da Irmandade, en xeral recrutadas no mundo urbano, e mais elaborar os padróns de veciños para percibir a súa contribución tiveron que pactar cos feudais. Sirva de exemplo a concesión ao mencionado conde de Lemos da cuarta parte das cantidades que os seus vasalos debían pagarlle á Irmandade a cambio da súa colaboración na confección de padróns (Pardo de Guevara cit. por Saavedra 2007: 28-29).

En definitiva, grazas a que o imposto da Irmandade foi cuase universal (apenas houbo exentos), os Reis Católicos remataron coa insubmisión fiscal galega aos servizos, se ben se tratou dunha carga moi gravosa (desorbitada, segundo a análise dos expertos) para o común, e chegou a desencadear protestas, resistencias ao pago e incluso motíns populares contra os atropelos dos seus executores. Por outra banda, a Irmandade -ademais de facer un efectivo traballo policial, colaborar no sometemento dos cabaleiros aínda levantadizos, 
comprar o apoio doutros e manter a administración da coroa- tamén serviu os Reis Católicos proporcionándolles subsidios extraordinarios e tropas para as campañas de Granada, Italia ou Bretaña (García Oro 1987: I, 331-340; Ladero 2005; Rubio 2016: 244-258).

Malia todo, no conxunto de Castela, a exacción da entidade xa non producía a finais da década de 1490 o preciso para o financiamento dunha nova guerra en Italia. Xa que logo, Fernando e Isabel tiveron que botar man outra vez das Cortes. Así, en 1498 desapareceu o duro tributo e ficou só a estrutura da Santa Irmandade para manter a orde. Pero en Galicia «el principal instrumento de que se valieron los Reyes Católicos para introducir la nueva forma que le dieron a la monarquía» (Diego de Clemencín cit. por Triano 2018: 437) deixaba outra pegada importante: cinco provincias internas, subdivididas en partidos menores, froito da suma ás anteriores catro demarcacións fiscais episcopais (o arcebispado 80 de Santiago xunto co bispado de Tui, Ourense, Lugo e Mondoñedo) dunha nova de reguengo: A Coruña-Betanzos. Velaquí a vontade de afirmación do poder real. En calquera caso, estamos a falar dunha artificiosa división interna do territorio ao servizo dos intereses rexios, pois cara ao exterior o reino seguiu sendo a unidade político-administrativa (Ladero 2005: 177).

\section{A volta dos servizos e loita pola recuperación do voto no século XVI}

Precisamente, unha vez aprobado un novo subsidio nas Cortes de 1500 (150000000 marabedís) para o casamento das infantas Isabel e Catalina, prometidas dos herdeiros de Portugal e Inglaterra, o gobernador Hernando de Vega e o alcalde maior Cornejo convocan, por orde real, unha xunta de "procuradores de las cinco provincias deste dicho reyno, de las ciudades, villas e lugares, cotos e felegresías» para distribuír a cantidade que lle tocou a Galicia no primeiro dos tres prazos nos que se faría efectivo o servizo: 6128000 marabedís (o 11,34 \% do total). A cifra era moi elevada en comparación coas achegadas por outras demarcacións fiscais de Castela (os peiteiros galegos pagaban unha porcentaxe que duplicaba o que lles correspondía tendo en conta a súa poboación, uns 250000 habitantes en 1500) e nos dous anos seguintes a cota do reino foi tamén alta (non menos dun $11,1 \%)$. De feito, pola súa achega porcentual, foi a segunda e incluso a primeira provincia contribuínte da coroa (no servizo de 1510 chegou a un 12,2 \%). Isto explica, segundo veremos axiña, a nova resistencia aos servizos e que Galicia fose o territorio máis beneficiado tras as indagacións tributarias do reinado de 
Carlos I (pasou dun 11,39 \% no período 1535-1537 a un 8,26 \% no de 1540-1542) (Carretero 1988: 98; Rubio 2016: 261-268; Saavedra 2007: 131-133).

Pois ben, aínda que non sabemos quen participou na reunión das cinco provincias que tivo lugar en Santiago en 1500, este encontro inaugura un modelo de asemblea distinto do das xuntas da Irmandade (Artaza 1998: 39-42; Fernández Vega 1982: 73; Ladero 2005: 176). Así, non só repartiu internamente a cota do servizo de Cortes, senón que tamén serviu para tratar "sobre otras cosas [...] que cumplían a la buena gobernación deste dicho reyno». En concreto, os procuradores coñecen unha carta dos Reis dirixida ás xustizas ordinarias para que castiguen os delitos nas súas respectivas xurisdicións, ordénaselles obrigar a veciñanza de cada unha das súas provincias ao mantemento dos camiños e lémbraselles unha pragmática sobre vodas e bautizos. Por último, déuselles aos procuradores a oportunidade de expor agravios, dos que recibirían xustiza11.

Concluíndo: entre as funcións destes novos congresos de provincias, cuxo número de membros irá reducíndose ata cinco rexedores das súas capitais na década de $1520^{12}$, estiveron, primeiro, garantir o cobro dos servizos de Cortes evitando os problemas do século xv; segundo, o desexo da monarquía e dos seus ministros en Galicia de manter o contacto cos dirixentes de cidades, vilas e lugares e lograr a súa colaboración na gobernabilidade do reino, e terceiro, ante a falla de representantes propios en Cortes, en certo modo compensar esta carencia permitíndolle á asemblea presentar queixas e súplicas ao rei e aos seus oficiais. Por conseguinte, dende 1500 e por iniciativa real, foise desenvolvendo un tipo de congreso representativo diferente das xuntas de Irmandade galegas e das xuntas dos outros territorios do norte de España que tampouco participaban nas Cortes (Asturias, a actual Cantabria e as provincias vascas). Ora ben, nas primeiras xuntanzas dos representantes das cinco provincias non atopamos información sobre o anhelado voto. Quizais o reivindicaron os concellos aproveitando a chegada ao trono de Filipe I e Xoana a Tola (1505-1506), pero en 1506 a negativa das dezaoito cidades a que os reis desen entrada a novos membros na súa asemblea foi rotunda:

11. «Año, 1500. Repartimiento y ordenanzas que hicieron los Procuradores de Galicia en la junta general que se celebró en Santiago el 6 de junio de dicho año», en Colección diplomática de Galicia histórica, ano I (1901), 317-319. A convocatoria real dirixida a Viveiro, no Arquivo Histórico Nacional (AHN), Concejos y Ciudades, c. 220 (Vivero), doc. 17.

12. Despois do servizo de 1515 , os procuradores do reino de Galicia que son convocados á cidade de Ourense xa son seis. Pero aínda non é unha xunta exclusiva das cabezas de provincia, posto que sabemos que o sexto, Lope de Mera, falaba por Baiona e por Tui (García Oro 1977: 282-283). Fernández Vega (1982: II, 89, nota 17) dá conta do envío dunha provisión de xaneiro de 1516 dirixida ao gobernador e aos alcaldes maiores de Galicia en resposta a unha relación de peticións dos «procuradores de las provincias dese dicho reino» reunidos en Ourense, vistas polo Consello Real. 
Por algunas leyes e ynmemorial huso está hordenado que diez e ocho çibdades e villas destos reynos tengan boto de procuradores de Cortes y non mas; e agora dis que algunas çibdades e villas destos reynos procuran o quieren procurar se les faga merçed que tengan voto de procuradores de Cortes, e porque de esto se recresçeria grand agrauio a las çibdades que tienen los votos del acreçentamiento, se syguiria confusyon, suplicamos á Vuestras Altezas que no den lugar que los dichos votos se acreçienten, pues todo acreçentamiento de oficios con votos está defendido por leyes destos reynos ${ }^{13}$.

E contestóuselles: «asy se hará». En 1512, xa con Fernando o Católico como gobernador de Castela, algunhas poboacións (tamén galegas?) teimaban para acadar a graza real. Inútil propósito. O rei é aínda máis partidario de manter unhas Cortes restrinxidas na contestación á petición dezanove: «Que a su Alteza 82 plaze de lo conseruar asi, porque la horden y costunbre antigua que en esto está dada es mui buena, e su Alteza no entiende en la quebrantar» ${ }^{\mathbf{4}}$.

En verdade, este formato dun congreso urbano tan limitado (máis fácil de manexar que as Cortes estamentais dos seus dominios aragoneses) era óptimo para o Católico e os seus obxectivos: obter e recadar cedo as axudas urxentes e cuantiosas que demandaba dos reinos de Castela. Polo tanto, pouco lle interesaban ao rei unhas Cortes que fosen a representación coherente do reino, mentres que as oligarquías das cidades que as monopolizaban aínda desexaban menos compartir os seus beneficios: poder político e fiscal coa xestión das axudas a prol deles e as súas clientelas nos seus amplos distritos, recompensas económicas polo seu traballo como procuradores, acceso á graza real e prestixio social (Carretero 2016: 80-81).

Feita esta aclaración, a primeira campaña para recuperar o voto de Galicia non chegaría ata 1518. Neste caso un novo rei, Carlos I (1516-1558), brindáballes a oportunidade aos concellos de acadalo. Por iso, ante a convocatoria das Cortes dese ano, aparecen distintos poderes de vilas e cidades (Lugo, Pontevedra, Muros, Noia, Santiago, A Coruña, Betanzos) anulando outro supostamente outorgado a Zamora para falar polo reino. O resultado foi a designación do licenciado Gonzalo Maldonado, provisor de Santiago, xunto con dous veciños da Coruña (Alonso López de Lemos e Juan Barcia) para exporlle ao monarca unha protesta contra a representación de Zamora. Así, estes comisionados

13. Cortes de los antiguos reinos..., IV, 233.

14. Cortes de los antiguos reinos..., IV, 249. 
negaron con contundencia o teórico dereito zamorano ${ }^{\mathbf{1 5}}$, mais o mozo soberano, neses momentos enfrontado coa maior parte das cidades e grandes señores de Castela polos agravios dos seus ministros borgoñóns, non atendeu as súplicas galegas (Carretero 1988: 17-18; Fernández Vega 1980: 80-81 e 84-85).

Chegamos, pois, a 1520, ano en que se abriu unha situación aparentemente máis propicia para lograr o difícil obxectivo: a convocatoria por Carlos, elixido emperador do Sacro Impero Romano Xermánico en 1519, das Cortes en Santiago e A Coruña (marzo-abril de 1520), chamadas para sufragar a súa coroación imperial e para reforzar a seguridade de Castela durante a súa ausencia. En efecto, sen entrar a fondo na análise das causas que farían estoupar a revolta ou revolución das Comunidades (trátase dunha vella polémica aínda non resolta) (Carlos 2020: 417-441), digamos que as Cortes reunidas en Galicia causaron unha forte oposición das cidades con voto, contrarias ás ambicións imperiais do rei, pois supuñan o abandono dos seus súbditos. Ademais, chegouse a pensar que a demanda dun elevado servizo, seguido do embarque inmediato da corte cara a Flandres para chegar a Aquisgrán, era unha última rapina do odiado séquito flamengo do monarca. Finalmente, a xuntanza dos procuradores lonxe das súas cidades e lugares habituais de celebración de Cortes semellaba unha nova táctica para vencer a súa resistencia a conceder o servizo. Non esquezamos que os ministros do rei someteron as cidades e os procuradores a unha forte presión para acadalo (Pérez 1977: 139-153).

Así as cousas, por vez primeira vemos como os grandes señores eclesiásticos e laicos galegos colaboran cos concellos na recuperación do voto. En parte, algo lóxico se temos en conta que despois da morte de Isabel a Católica, en 1504, os problemas da sucesión dinástica en Castela supuxeron unha grande inestabilidade política. E, claro, os persoeiros máis ambiciosos do antigo reino procuraron recuperar o poder perdido para dirixir o seu goberno. Segundo García Oro (2000: 118-120), os protagonistas deste proxecto, que tamén buscaba reivindicar a singularidade galega ante os reis de Castela, eran don Rodrigo Álvarez Osorio, conde de Lemos; don Fernando de Andrade e o arcebispo don

15. Unha vez feita a revocación do «poder e facultade que la dicha çibdad de Çamora tenía de hablar por ellos en las dichas Cortes [...], los apoderados] suplicaban al rey nuestro señor que no se entrometiesen de hablar por el dicho reyno de Galizia en las dichas Cortes ni en otras en ningund tiempo que sea, e suplicaban al rey nuestro señor que no los admitiese por tales procuradores, ni los mandare oír en nombre del dicho reyno de Galizia, protestando como protestaron que si la dicha çibdad de Çamora o sus procuradores contra lo que dicho es en las dichas Cortes, o en otras de aquí adelante, se entrometieren de hablar por el dicho reyno de Galizia, que ellos protestaban de no estar por ello, ni por lo que ellos ansí conçedieren e otorgaren, e que para ello no han poder alguno». Transcrito por Carretero (1988: 18). As conxecturas sobre o outorgamento do suposto poder, en Fernández Vega (1980: 81-84). 
Alonso de Fonseca III. Para empezar, un deles, Fernando de Andrade, heroe das guerras de Italia e figura próxima ao novo emperador, alentou na Coruña e Betanzos, cidades onde posuía asento de rexedor, unha proclama de lealdade á coroa. Proclama na que Zamora foi denunciada por seguir os pasos da rebelde Toledo para, a continuación, pedir ao monarca e ao Consello Real a retirada da representación galega da cidade do Douro. Da firmeza do propósito de ambas as poboacións de reguengo dá fe o envío á corte do procurador Juan Barcia para promover a demanda (García Oro 1994: 117).

A continuación, Andrade interveu persoalmente e fíxoo con tal vehemencia, segundo recollen as crónicas, que rematou sendo desterrado á Coruña. Estamos a falar da célebre protesta protagonizada durante o congreso das Cortes no convento de San Francisco en Santiago, e nela o conde foi acompañado polo arcebispo de Santiago, Fonseca III, e o conde de Benavente (Sandoval 1846: 84 III, 39-41) ${ }^{\mathbf{1 6}}$. En todo caso, as súas palabras tampouco foron escoitadas polos procuradores, e unha última tentativa galega ofrecendo o servizo que os vogais zamoranos non votaban só supuxo un argumento de presión para que Carlos I acadase a súa conformidade ${ }^{17}$.

Tras a aprobación da axuda, marchou o rei para se converter en emperador e estoupou a temida guerra civil, a guerra das Comunidades de Castela (1520-1521), en nome da liberdade contra o despotismo. A Santa Xunta das cidades alzadas fronte ao monarca axiña gañou terreo e pretendeu unha reorganización da Monarquía na cal as Cortes desempeñarían un papel central representando o reino; e nesas futuras Cortes Galicia si que tiña voz. Aínda que pouca: dous procuradores dos seus bispados «porque son pequeños» (Pérez 1977: 529-530) ${ }^{\mathbf{1 8}}$.

Ignoramos se as cidades galegas, que si eran moi pequenas ${ }^{19}$, coñeceron ese proxecto comuneiro, se ben Betanzos e Ourense se deixaron tentar pola Santa

16. Fernández Vega (1980: 85-86) refire tamén as versións do incidente de Pedro Mártir de Anglería e a de Santacruz. 17. «... [L]legaron ante S. M. Francisco Ramírez e Bernaldo de Ledesma, procuradores de Cortes de la dicha ciudad de Çamora, e en presencia de S. M. el dicho señor gran Chanciller les dixo que respondiesen claramente lo que querían hacer en lo del servicio porque açebtaría S. M. el servicio que se le ofrescia por el Reyno de Galicia, pues su Alteza estaba dentro del Reyno y el Reyno ge le ofrescia». Cortes de los antiguos reinos..., IV, 320.

18. «En los Capítulos de lo que ordenavan... la representación en Cortes quedaba organizada de una forma más compleja: cada diócesis enviaba a tres procuradores: un representante del clero secular, un representante de los caballeros y otro de los comuneros; además, el conjunto de los caballeros (hay que entender la alta nobleza, excluyendo a los caballeros de las ciudades, ya representados) designaba a dos procuradores; las órdenes religiosas podían tener también dos representantes» (Pérez 1977: 529-530, nota 2).

19. Só Pontevedra, Santiago, Ourense e A Coruña superaban os 1000 veciños (arredor de 4000 habitantes) a finais do século xvi (Fernández Cortizo 2012: 62-63). 
Xunta (García Oro 1994: 120). Pero sabemos que nesta conxuntura os magnates laicos e os prelados tiveron problemas cos seus vasalos. No verán, estes e mais os veciños das poboacións de reguengo levantáronse violentamente contra a recadación do servizo de 1520. Conforme a historiografía, foron meras revoltas antifiscais. Porén, o certo é que os axentes da coroa tiveron traballo dabondo para sufocar os motíns (Santiago, Lugo, Mondoñedo, Pontevedra, Ourense, Betanzos...) dos que falan as testemuñas dunha pescuda sobre «ciertos maravedís» que o licenciado Escalante tomou dese servizo. De feito, tratouse da crónica dun conflito anunciado porque «el governador e alcaldes mayores al dicho tienpo en la Ciudad de la Coruña llamaron e juntaron los procuradores de las provincias para que pagasen el dicho servicio e que los dichos procuradores no quisieron consentir diziendo que los pueblos que estavan alborotados los matarían» ${ }^{20}$.

Visto o visto, os señores, que non esquecían aínda a revolta irmandiña, tomaron medidas para manifestar a súa adhesión ao emperador e previr males maiores. Dende logo, non deixaron sumarse á revolta as cidades galegas, e cando remataba o mesmo ano vinte, so o pretexto de evitar o contaxio comuneiro, convocaron un encontro na vila de Melide erixíndose en representantes do reino malia non ter autorización dos ministros do rei en Galicia. Tal era o poder que exercían.

Pois ben, coa presenza destacada do arcebispo Fonseca e Fernando de Andrade, fidalgos, cabaleiros, e procuradores doutros señores leigos e eclesiásticos, tivo lugar en decembro a Asemblea de Melide. Nela acordaron unha serie de súplicas dirixidas ao rei e a súa nai, a raíña dona Xoana, entre as que figuraba a solicitude da «merced» do voto, usurpado por Zamora; e rexeitaron tamén a satisfacción de calquera outorgamento que a devandita cidade fixese dende as Cortes da Coruña (capítulos VII e VIII) ${ }^{21}$. Pero desta vez tampouco don Carlos cedeu aos rogos. O 29 de marzo de 1521 aprazou o asunto dende Alemaña e á súa volta a España, en 1522, desestimou a opinión dos ministros favorables á petición dos dirixentes galegos e á dos partidarios de castigar a Zamora. O emperador creu que ese tipo de penas faría renacer as tensións (Fernández Vega 1980: 87-89; Silva Ferreiro 1925: 26-27; Pérez 1977: 374 e 579).

20. O documento transcrito por Danvila $(1889,5: 623-631,628)$ é ben coñecido. Non así a nova desta inédita xunta de provincias, que, ademais, se negou a colaborar cos axentes da monarquía.

21. «Capitulaciones del Reino de Galicia, para el servicio de Su Magestad en el tiempo de las Comunidades», Galicia Diplomática, I:14, 97-100. 
Por outra banda, coa derrota dos comuneiros (1521) e o regreso do flamante emperador, a inestabilidade política que nos primeiros anos do reinado de Carlos lles permitira aos magnates cobrar un peso inusitado na dirección de Galicia (Fonseca e Andrade pediron e lograron ser capitáns xenerais en 1521) finalizou. Ata ese momento a insubmisión fiscal foi xeneralizada. Non se pagaban as rendas reais e mesmo algúns señores se apropiaron delas. Tampouco os servizos de 1518 e 1520 estaban satisfeitos en 1523 (García Oro 1994: 132-134). Xa que logo, a súa maxestade decidiu acabar dunha vez por todas coa rebeldía galega e afirmar a autoridade real. De aí o afastamento definitivo dos aristócratas de maior rango do goberno do reino (atraídos á corte ou enviados a diversas misións polos extensos dominios da Monarquía), a elaboración de novos padróns fiscais (1528-34) que serviron para rematar co impagamento dos servizos (ordinario e extraordinario) de Cortes, e a recuperación das rendas reais usurpadas. Así 86 mesmo, Carlos I fortaleceu os órganos de xustiza e goberno da coroa (a Real Audiencia e o gobernador capitán xeneral, considerado na práctica un vicerrei) e, por último, a imitación das Cortes, converteu os congresos das provincias galegas nunha asemblea representativa do reino na cal participaban exclusivamente as súas capitais (cinco dende 1528 ata metade de século e, a partir de entón, sete como consecuencia da secesión do bispado de Tui da provincia de Santiago e da división da bicéfala A Coruña-Betanzos).

Con este novo panorama político, os grandes señores deixaron paso na iniciativa de recuperar o voto ás cidades cabezas de provincia a través das Xuntas do Reino ${ }^{22}$. Estas asembleas, pois, identificáronse coa comunidade política de Galicia. Nun primeiro momento, vímolas vencelladas aos servizos votados polas Cortes, pero co transcorrer do tempo irían institucionalizándose e ampliando as súas funcións, sobre todo por mor das crecentes necesidades militares (tropas, fornecementos) e fiscais da monarquía, abafada polo elevado custo das continuas guerras que librou. Xa que logo, despois do regreso do césar Carlos, á repartición dos servizos de Cortes sumóuselle a capacidade para aprobar axudas particulares de Galicia ao rei (Artaza 1998: 45-46; Fernández Vega 1982: II, 74; Fernández-Villamil 1962: II, 236 e III, 1 e ss.). En contrapartida, a Xunta tiña o dereito de expor queixas e facer peticións, como a do voto, unha aspiración considerada polos servidores do rei en Galicia para obter medios destinados á súa defensa. Este foi o caso do mariscal de Navarra, gobernador e capitán xene- 
ral, quen en 1544, nun memorial dirixido ao emperador, di que coa cantidade obtida a cambio da graza bastaría para fortificar A Coruña. Na contestación do rei non houbo sorpresa: foi outra negativa clara a facer uso do seu «poderío real absoluto» (Fernández Vega 1980: 90).

Antes, en 1533, tras distribuír a cota do servizo asignada a Galicia, os deputados das cinco provincias aproveitan a ocasión para pedir un procurador que defenda na corte os intereses do reino, pois alegan que Zamora non o facía e, ademais, repartía cantidades elevadas dos servizos para descargar a súa terra (Fernández Vega 1982: III, 334). Da primeira queixa temos confirmación empírica (Carretero 1988: 17) e da segunda, verdadeira ou falsa, lembremos o comentado sobre o importante gravame que supuñan eses subsidios extraordinarios ata comezos dos anos corenta para os peiteiros galegos (Saavedra 2007: 137-38).

A falta doutras novas, debemos agardar a 1557 para topar outra acción conxunta das cidades. Daquela, a recente subida ao trono de Filipe II (1556-1598) e os seus apuros fiscais, ocasionados pola guerra con Francia (primeira bancarrota do seu reinado), brindaban unha boa oportunidade para recuperar o voto. Así, os comisionados de cinco das sete cabezas de provincia (Santiago, A Coruña, Betanzos, Lugo e Mondoñedo), a instancias dos ministros do soberano, acordan en Valladolid ofrecer 20000 ducados pola graza real ${ }^{23}$. Segundo esas capitulacións de 1557, os rexedores dos concellos serían os únicos individuos con dereito $\mathrm{a}$ ir ás Cortes. E, isto é o máis importante, estableceuse unha quenda de asistencia que contemplaba a participación de Ourense e Tui, as cidades ausentes. Agora, malia sufriren outro fracaso, hai indicios de que o obxectivo estivo a piques de ser alcanzado (Fernández Vega 1980: 90-93; Silva Ferreiro 1925: 28-31). Non obstante, as Xuntas do Reino seguiron co seu empeño. Porén, evidéncianse novas ausencias ou discrepancias, como en 1573, pois nin Santiago nin Tui concederon poderes para negociar a recuperación do voto (Fernández Vega 1980: 94-95). Velaquí outro problema central na consecución da mercé do rei: as disputas entre as cidades, case sempre motivadas polo posto na rolda de procuradores e incluso polo desfrute exclusivo da representación galega.

En principio, todos os concellos admiten que Galicia debe ter só dous procuradores (o mesmo número que tiña cada unha das cidades que asistían ás Cortes); isto é, unha parella formada por rexedores de dúas capitais segundo a quenda establecida en función da súa antigüidade (Santiago, A Coruña, Betan-

23. «Capitulaciones de las ciudades de Galicia sobre el voto en Cortes. - Año de 1557», transcrición de Pablo Pérez Costanti, en Colección de documentos históricos del Boletín de la Real Academia Gallega, II, 201-208. 
zos, Lugo, Mondoñedo, Ourense e Tui) e o número impar das provincias. Pero Santiago, a máis poderosa das sete, e capital da provincia máis rica e poboada, que tamén aspiraba a ser recoñecida como cabeza do reino, non quixo respectar o acordo de 1557: desexaba ter representante sempre que se convocasen Cortes e non cedeu ata a transcendental Xunta de 1599. Despois, a pesar das protestas, Compostela quedará satisfeita coa dobre quenda da que gozaría como consecuencia da rolda finalmente aceptada. Así e todo, sen dúbida, a peor ameaza sería a tentativa das cidades de reguengo (A Coruña, Betanzos e Ourense) de non compartir a representación do reino coas «abadengas» (Santiago, Lugo, Mondoñedo e Tui), cousa que, por fortuna, tamén se solucionou. Falaremos disto chegado o momento. Retomemos agora o fío do tempo.

Pois ben, dende o último cuarto do século Xvi o negocio do voto tivo un aspecto positivo: a cooperación das cidades e das súas oligarquías fidalgas coa 88 nobreza titulada e os persoeiros galegos na corte. Trátase dun aspecto capital porque, insistimos, as poboacións que monopolizaban as Cortes se opoñían con moita forza á súa ampliación. De feito, Zamora moveu todos os seus recursos contra a pretensión galega ata chegar a poñer un preito sobre o tema dende, aproximadamente, 1574. Pero tamén ensaiou a vía do diálogo; iso si, con torpeza. Referímonos á carta dirixida polo concello zamorano ao "Reino de Galicia en su Audiencia» solicitando novas do que sería conveniente pedir ao rei en nome dos galegos nas Cortes de 1579. E a contestación do tribunal foi tallante. Zamora estaba mal informada: ese «negocio» non era da súa competencia «por tocar sólo á las cabezas de provincias en particular, las cuales, en nombre deste Reino tenian muchos dias há hechas sus protestaciones y requerimientos en forma á esa ciudad, que no se entrometan en Córtes á tratar ni ofrecer cosa alguna en su nombre, por no tocalle tal cuidado» ${ }^{24}$. Así mesmo, esta contestación da Audiencia é un dato máis que avala a consideración da xunta das sete cidades como voz de Galicia, feito corroborado pola súplica da asemblea dirixida en novembro a Filipe II pedindo a restitución do voto e que Zamora non fale polo reino, «porque jamás le dirá su intento». Por outra banda, este escrito foi entregado persoalmente ao rei polo procurador xeral do reino Ares González, e contou co apoio dun eclesiástico galego que estaba na cúspide do poder central: 
Antonio Mauriño de Pazos, presidente do Consello Real (1579-1582) (Fernández Duro 1883: $54-55)^{25}$.

Mauriño de Pazos non conseguiu persuadir o rei da xustiza da causa de Galicia, polo que o peso da súa promoción na Corte lle foi confiada logo á casa de Lemos. Porén, nin don Pedro, o quinto conde, nin o seu tío don Rodrigo de Castro, o célebre cardeal, obtiveron mellores resultados manexando os argumentos facilitados por Ares González. Entre eles, o de que, coa devolución do voto ao reino de Galicia, Filipe II conseguiría «asegurar su conciencia en tomar por mano del la hacienda que se le diese, pues Zamora no se le puede dar». Ademais, o monarca debería considerar outro aspecto importante: o donativo que faría Galicia pola mercé (Fernández Duro 1883: 57). Velaquí a clave para conseguir a súa vella arela: o voto tiña un prezo. En 1557 vimos unha oferta de 20000 ducados e en 1573 a suma déixase ao arbitrio dos enviados a Madrid (Fernández Vega 1980: 95), pero á morte de Filipe II aínda non coñecemos ningunha cifra. Ata onde chegaría a poxa do reino polo voto?

\section{O prezo do voto}

Filipe III sucedeu o seu pai en setembro de 1598, mais non tiña nin o carácter nin a vontade de mando do Rei Prudente. Polo tanto, deixou o poder nas mans dun valido: don Francisco Gómez de Sandoval, o duque de Lerma, cuñado do conde de Lemos, don Francisco Ruiz de Castro. Abríase, pois, unha nova oportunidade para o reino de Galicia. Así, contando co beneplácito da Audiencia, os procuradores das sete cidades reuníronse a principios de 1599 na Coruña para tratar sobre a obtención do voto e o nomeamento dunha ou varias persoas para pedilo «a su Magestad y a los señores del su Consejo», xunto con outras súplicas para beneficio do reino ${ }^{26}$. Mais o congreso foi tenso porque, lembremos, Santiago non aceptara a quenda de 1557. Desexaba enviar procurador sempre que se convocasen Cortes e iso motivou a exclusión dos seus rexedores de varias xuntas previas. De aí que, antes de nada, os outros seis membros da asemblea intentasen que o compostelán Lope Osorio de Mercado aceptase o acordo do ano cincuenta e sete e as decisións tomadas pola maioría da Xunta. Pero Osorio

25. Neste escrito falla a sinatura do vogal compostelán, algo que, como no caso das Cortes, non invalidaba o acordo (Dios 1991: 261-271).

26. Arquivo Histórico Universitario de Santiago (AHUS), Arquivo Municipal de Santiago (AMS), Libro de Juntas del Reino de Galicia (LJR) 1599, AM 486, ff. 32v-33. 
non cedeu ás presións dos outros capitulares (mesmo chegaron a ameazar coa súa expulsión e a exclusión de Compostela do voto). Xa que logo, para evitar incidentes, tal e como desexaba o vogal de Santiago, a elección dos rexedores que se acordou enviar á corte fíxose diante do gobernador. Era unha novidade que non debería repetirse, pero, en calquera caso, permitiu solucionar a crise.

Paradoxalmente, Lope Osorio de Mercado e o procurador de Betanzos Fernán Díaz de Ribadeneira foron os elixidos para conseguir redimir o voto e promover outros asuntos de interese común na corte. A súa comisión duraría dous anos e, unha vez concluídos, lograsen ou non o voto, consideraríase consumida a vez de Santiago e Betanzos. Desta maneira, estableceuse unha nova quenda para asistir ás Cortes favorable á cidade do Apóstolo, porque a iniciaba con Betanzos, despois ían A Coruña e Lugo, Mondoñedo e Ourense e a cerraba xunto con Tui (dúas veces cada catro chamamentos a Cortes) ${ }^{27}$.

90 Sen entrarmos na análise da longa instrución dada pola Xunta aos rexedores Osorio e Díaz de Ribadeneira (Fernández-Villamil 1962 I: 18-23), o máis salientable para o noso relato é a inxenua pretensión de obter a voz en Cortes pola vía de graza «sin ofrecer dineros» (representaríanse os servizos de Galicia nas guerras pasadas e a presión fiscal que sufría), deixando a oferta dun donativo para cando esgotasen todas as esperanzas e, de ser o caso, ofrecendo «lo menos que pudieren por la pobreza del rreyno», informando axiña para recibir instrucións ${ }^{28}$. É certo que Galicia, como manifestaban os procuradores da Xunta, sufría «mucha hambre y peste», azoute que padecía neses momentos boa parte de Castela; porén, a monarquía, falta de diñeiro, precisaba con urxencia novos ingresos e non tivo máis remedio que convocar Cortes. O obxectivo do duque de Lerma era a renovación do chamado servizo de millóns, axuda extraordinaria outorgada co gallo das perdas provocadas polo desastre da Armada Invencible en 1590, cousa que Filipe II non conseguiu. Pois ben, en 1600 o Parlamento de Castela ofreceu 18 millóns de ducados pagadoiros en seis anos baixo unha serie de condicións (escritura de 1601) que supuñan un claro avance a prol do reino respecto das de 1590 (Feros 2002: 283-187) ${ }^{29}$. Xa que logo, as cidades con voto en Cortes endureceron máis se cadra a súa vontade de monopolizar a asemblea.

27. AHUS, AMS, LJR 1599 cit., f. 17. A instrución da Xunta a Osorio e Ribadeneira, nos ff. 25-30.

28. AHUS, AMS, LJR 1599 cit., f. 26v.

29. A literatura sobre o tema é xa moi ampla e non para de medrar. Un achegamento aos servizos de millóns e Galicia, en Artaza (1988: 319 e ss.) e Saavedra (2007). 
De calquera maneira, segundo pasan os meses do primeiro ano en Madrid dos comisionados galegos, vemos como medra a suma considerada aceptable para recuperar o voto. De 30000 pasan a 50000 ducados e chegan a considerarse os 60000 en decembro de $1601^{30}$. Así e todo, o novo conde de Lemos, Pedro Fernández de Castro, esixiu en 1602 ao concello de Santiago liberdade para ofrecerlle ao rei o donativo que considerase oportuno. Se non, abandonaría o negocio (Silva Ferreiro 1925: 52-57).

Non temos aquí espazo para contar polo miúdo as vicisitudes das xestións feitas polos procuradores enviados a Madrid polas capitais de provincia, as Xuntas do Reino celebradas en 1608 e 1613 e as manobras dos patróns de Galicia na corte ata 1621, un ano clave para esta historia. Baste dicir que Zamora, dotada dun xulgado do servizo de millóns por mor do pactado entre o rei e as Cortes en 1601, tiña dereito «a visitar las çiudades y villas de su distrito y provincia y averiguar los fraudes que en la administración de dicho serviçio se hubieran fecho» (Fernández Vega 1980: 104). Naturalmente, o envío dos visitadores zamoranos ás cidades galegas aumentou a súa xenreira contra a capital duriense. O resultado foi outro preito para evitar esas inspeccións, que continuaron ata 1621 (Eiras 1995b: 35). E precisamente ese ano de 1621 subiu ao trono o mozo Filipe IV, unha nova oportunidade para materializar o vello anhelo. Sobre todo porque vencía a Tregua dos Doce Anos asinada cos rebeldes holandeses e a monarquía precisaba reforzar a súa mariña de guerra. De feito, o programa de rearmamento naval comezara nos últimos anos do reinado de Filipe III, quen, falto de fondos, fortaleceu a frota atlántica ou Armada do Mar Océano a través dunha serie de convenios coas provincias de Biscaia (1617), Guipúscoa (1618) e as Catro Vilas de Cantabria (1618). Convenios mediante os que eses territorios se comprometían a construír e formar as súas respectivas escuadras, que operarían baixo o mando de oficiais nativos.

Así as cousas, o gobernador capitán xeneral de Galicia, o marqués de Cerralbo, viu a oportunidade de dispoñer dun escuadrón de galeóns para combater os piratas e corsarios que ameazaban as costas do reino, algo que os seus antecesores non lles lograran arrincar ás xuntas das cidades durante o século anterior (Artaza 1996: 446-50 e 2020: 131). Por conseguinte, á volta dunha viaxe a Madrid na cal avogou pola aspiración das elites galegas, Cerralbo propúxolle o un de outubro de 1621 á Xunta do Reino ofrecer un servizo de 100000 ducados a cambio da graza. Pero baixo a condición de investir esa cantidade na 
fabricación e o mantemento de catro ou seis navíos que limpasen de inimigos o litoral galego. A proposta, pois, contentaba as aspiracións da coroa e do reino. Por outra banda, segundo o marqués, o voto e mais a actividade dos buques de guerra rematarían con boa parte das penas de Galicia e serían a base dun futuro próspero e glorioso. A escuadra converteríase tamén nunha escola de mariños civís e militares, brindándolles aos últimos posibilidades de gañar mercés, e a xuventude nobre disporía dun medio para se promover sen saír do reino. Sen dúbida, todas estas vantaxes suplementarias eran moi interesantes para as oligarquías das sete cidades, na súa maior parte compostas por pequenos fidalgos que precisaban do patrocinio real para medrar.

A Xunta, pois, acordou facer esa oferta baixo certas condicións, entre as que destacan o pagamento do servizo en catro anos por todos os galegos sen atender ao seu estado social, e que a Xunta e as cidades controlasen a repartición 92 equitativa do subsidio que tocaba aos respectivos provincianos e a súa xestión. Non menos importante foi que o rei se encargaría do mantemento da escuadra.

Naturalmente, nesta ocasión, tamén se lles pediu axuda aos cortesáns galegos, entre os que destacaron o conde de Lemos; don Baltasar de Zúñiga, conselleiro de Estado e Guerra e tío do conde de Olivares, favorito de Filipe IV, e o confesor real frei Antonio de Sotomayor.

En calquera caso, os 100000 ducados para armar a escuadra foron considerados o prezo xusto polo voto. Así, en xaneiro de 1622 o rei ordenoulle á Real Audiencia convocar os procuradores das sete cidades «para repartir y asegurar» o donativo. Polo tanto, os ministros de Filipe IV querían que, antes de que o soberano fixese a mercé, primeiro se repartise o servizo ${ }^{31}$. E, pola súa parte, a Xunta do Reino manobraba para garantir a contribución dos eclesiásticos e dos cabaleiros, mentres gañaba tempo para ver materializado o voto (Eiras 1995b: 44).

Antonio Eiras considerou este congreso de 1622 «irrelevante» polo seu contido (Eiras 1995b: 44), pero, pola contra, nós cremos que nel se xogou a mercé porque a principal ameaza para obtela nese momento non era externa, senón interna. En efecto, segundo adiantamos, os procuradores rifaron de novo a causa da quenda, pois xulgaron consumida a vez de Santiago e Betanzos polo envío dos seus rexedores á corte para obter o voto a principios de século. Mais o fundamental foi que nesa xunta se atallou a tamén mencionada tentativa das

31. AMC, correspondencia da Xunta do Reino, carta do 3 de abril de 1622 do padre Sotomayor á Xunta. No reverso advírtese de que este documento é importante por se algunha cidade non se axusta ao que nela se di. Polo que atinxe a Ourense, cidade de reguengo de forma provisoria dende 1571, non o foi de xeito definitivo ata 1628 (López Díaz 2006: 133). De aí o silencio do padre Sotomayor sobre a súa condición. 
cidades reguengas (A Coruña, Betanzos e Ourense) de apropiarse da representación de Galicia baseándose nun capítulo de Cortes que impedía a presenza nas súas reunións das abadengas. Da inquedanza causada polo problema («hablillas» que chegaran a Madrid) no confesor Sotomayor, figura decisiva neste asunto e na construción da escuadra, temos un testemuño precioso: a súa misiva do 3 abril dirixida á Xunta. Nela, o padre confesor advirte do perigo de intentar excluír a Santiago, Lugo, Mondoñedo e Tui («que quieren antes estar subjetas a Çamora que a Betanços») porque o real ánimo desexaba beneficiar a todo o reino, pero Zamora contradicía a restitución do voto, e pola ambición duns poucos e a conseguinte división dos concellos podería perderse antes de facerse efectiva. De aí a importancia dos acordos do 18 de marzo e o 25 de xuño. Entón, sen a menor reserva, todos os membros da Xunta aceptaron que a mercé sería para o reino e as súas sete cidades ${ }^{32}$.

En verdade, Zamora, coa axuda das demais localidades que monopolizaban o Parlamento de Castela, fixo todo o posible para evitar a perda do seu privilexio representativo. Porén, daquela primaba a vontade do monarca. Tal e como manifestaron os defensores da restitución do voto en Cortes a Galicia, esta era unha regalía dos monarcas casteláns (Fernández Vega 1980: 107-115; Thompson 1989: 194-195). Xa que logo, o 13 de outubro de 1623 Filipe IV concedeu oficialmente a graza ${ }^{33}$ e, así, o conde de Salvaterra, xunto con don Antonio de Castro y Andrade, membro do Consello de Ordes, entraron a formar parte das Cortes o 17 de outubro.

Cómpre dicir que as cidades, sen prexuízo da quenda establecida, deixaron o nomeamento destes primeiros procuradores galegos da Idade Moderna nas mans de dous grandes valedores da súa causa: o padre Sotomayor e o conde de Gondomar. En realidade tiveran como primeira opción o favorito do rei, o conde-duque de Olivares, e o seu cuñado, o conde de Monterrey. Sen dúbida, como os finalmente elixidos, dous procuradores adictos á coroa que influirían nas decisións das Cortes. Así mesmo, a nobreza cortesá galega tamén obtivo proveito da presenza do reino nas Cortes durante o século XVII. Por outra banda, a elección dos aristócratas como procuradores foi unha mostra máis do seu ascendente sobre a fidalguía que controlaba os concellos das sete cidades. En 1646 o conde de Lemos logrou ser elixido polas dúas que tiñan a vez para

32. Actas de las Juntas del Reino de Galicia, Santiago de Compostela, Xunta de Galicia, I, 234-235 e 241-242.

33. "Cédula de Su Magestad para que Galicia tenga boto en Cortes», en Actas de las Cortes de Castilla publicadas por acuerdo del Congreso de los Diputados, Madrid, Fortanet, 1917, t. 40, 9-15. 
nomear procurador, Ourense e Mondoñedo, e, para solucionar o problema, a Xunta do Reino propón ao conde que renuncie a unha rexedoría a favor do seu primoxénito, o conde de Andrade. Ademais, o deputado coruñés vota o apoderamento do mozo para «obligalle el rreyno en tan tiernos años continúe la merced que sus predecesores han hecho a este rreyno y en que su Casa hes tan Ynteresada, pues en ella tiene tantas tierras y vasallos por quien debe mirar» ${ }^{\mathbf{3 4}}$. Tamén, nunha asemblea con pouca presenza de títulos, os condes de Altamira e Monterrey representaron a súa terra natal en 1649 (Domínguez Ortiz 1961: 178).

\section{Vinganza tardía}

Nin o voto en Cortes nin a escuadra do reino trouxeron os beneficios esperados. Os galeóns perdéronse fóra das costas galegas (Getaria, 1638; batalla das Dunas, 94 1639) e piratas e corsarios seguiron sendo un pesadelo das poboacións mariñeiras. Aoínda por riba, a construción e o mantemento da escuadra xeraron unha débeda e un longo preito que non remataron ata moi entrado o século XVIII (Artaza 1996: 479-483; Fernández-Villamil 1952). E polo que atinxe ás Cortes, sen entrarmos no exame da actividade dos procuradores, non serviron de moito para remediar os problemas do reino. Ademais, Filipe IV continuou convocando, cada vez con maior frecuencia, a Xunta do Reino para solicitar servizos particulares de Galicia (tropas, diñeiro, fornecementos militares). Por conseguinte, como nos tempos da representación zamorana, a defensa dos intereses galegos na corte debeuse confiar a rexedores das capitais de provincia enviados ex profeso. Pero o peor foi que co voto os particularismos das elites urbanas se acentuaron máis se cadra e chegaron a provocar graves prexuízos. En palabras de Enrique Fernández-Villamil (1962: I, 42), o primeiro autor dunha monografía sobre as Xuntas do Reino, subsistiu «un poso de municipalismo excesivo, de privilegio de ciudad que trataba de sobreponerse al de comunidad de ciudades en un orden superior de Reino».

Porén, o voto permitiulle á Xunta do Reino seguir congregándose sexenalmente despois de 1716, cando os Borbóns puideron prescindir das súas axudas. De feito, agás algunha excepción, o motivo da convocatoria da Xunta foi a prórroga sexenal do servizo de millóns e o sorteo dos seus comisarios, que facía en lugar das cidades como en Castela despois de 1665, e o apoderamento dos procuradores que debían asistir ás xuras reais. Non obstante, a asem- 
blea das sete cidades continuou enviando queixas e peticións ao rei sobre as supostas necesidades galegas. De feito, os deputados da Xunta dirixíronse ao monarca e aos seus ministros como o "Reino de Galicia junto en Cortes». Por tanto, cando en maio de 1808 os galegos se levantaron contra Napoleón a prol de Fernando VII, foi a Xunta, en calidade de Cortes, a que pasou a dirixir Galicia. E por exercer como un goberno soberano foi acusada de independentismo por algúns contemporáneos; pero o certo é que, dende o primeiro momento, buscou a unidade de todos os territorios alzados contra Napoleón e o seu irmán Xosé, o "rei intruso». Aínda máis: o 17 de xuño propuxo celebrar Cortes xerais e, como suxería Asturias, desexaba que fosen conforme un modelo representativo baseado no peso demográfico. Entón, Galicia, con case 1,4 millóns de habitantes, era a provincia máis poboada de España e a súa representación pasaría de dous a catorce procuradores. Finalmente, a Xunta pedía unhas Cortes xerais da nación española na que participarían todos aqueles territorios de Castela sen voto e tamén os da antiga coroa de Aragón (Aragón, Cataluña, Valencia, Mallorca), esquecendo os seus vellos foros e parlamentos estamentais.

A Xunta do Reino desapareceu como consecuencia da entrada das tropas francesas en Galicia en xaneiro de 1809. Con todo, nas revolucionarias Cortes soberanas de 1810 que elaborarían a Constitución de Cádiz, a representación galega foi a máis elevada: 25 deputados, seguida a distancia por Cataluña e Valencia, con 17. Parece, pois, que houbo unha sorte de vinganza, malia que tardía, polas humillacións pasadas dende o século XV ata 1623. Por outra banda, a Galicia de comezos do século XIX non era, como cando perdeu o voto, «un termo puramente xeográfico no que [só] contaban politicamente o arcebispo de Santiago e os señores prevalentes en cada momento» (García Oro 2000: 118). Pero, como denunciaran os ilustrados, a aínda abafante señorialización era un grave estorbo para o exercicio equitativo da xustiza e o progreso económico-social do reino (Saavedra 2013: 27-37). Por iso os deputados liberais galegos nas Cortes de Cádiz desempeñaron un papel protagonista na elaboración da norma que pretendeu rematar con ela: o decreto do seis de agosto de 1811 de abolición dos señoríos, que supuxo a fin da vasalaxe e a conversión de todos os españois en cidadáns iguais ante a lei. Iniciouse, así, o longo tránsito de Galicia á modernidade (Artaza 2017: 218-221). 


\section{- Referencias bibliográficas}

ArtazA, Manuel Ma de (1996): «Representación política y guerra naval en la Galicia de los Austrias», Anuario de Historia del Derecho Español, 66, 445-496.

ArtazA, Manuel Ma de (1998): Rey, reino y representación: la Junta General del Reino de Galicia, Madrid, CSIC / Escola Galega de Administración Pública.

ArtazA, Manuel Ma de (2011): «Betanzos: la agonía de una capital del Antiguo Régimen», Anuario Brigantino, 34, 237-268.

ArtazA, Manuel $\mathrm{M}^{\mathrm{a}}$ de (2017): «De reino a región: el caso de Galicia en perspectiva institucional», en Juan Baró Pazos (ed.): Repensando la articulación institucional de los territorios sin representación en las cortes del Antiguo Régimen en la Monarquía Hispánica, Madrid, Marcial Pons, 195-238.

ArtazA, Manuel Ma de (2020): "Galicia en la Edad Moderna, un reino sin cabeza», Estudis: Revista de Historia Moderna, 46, 119-144.

BARó Pazos, Juan (ed.) (2017): Repensando la articulación institucional de los territorios sin representación en las cortes del Antiguo Régimen en la Monarquía Hispánica, Madrid, Marcial Pons.

Carlos Morales, Carlos Javier de (2020): «Las Comunidades de Castilla, un conflicto en el proceso de configuración de la Corte», en Carlos Javier de Carlos Morales / Natalia González Heras (dirs.), Las Comunidades de Castilla: Corte, poder y conflicto, Madrid, Polifemo.

Carretero Zamora, Juan Manuel (1988): Cortes, monarquía, ciudades: las Cortes de Castilla a comienzos de la época moderna (1476-1515), Madrid, Siglo XXI.

Carretero Zamora, Juan Manuel (2001): «La consolidación de un modelo representativo: las Cortes de Castilla en época de los Reyes Católicos», en Julio Valdeón Baruque (ed.), Isabel la Católica y la política, Valladolid, Ámbito / Instituto Universitario de Historia Simancas, 259-293. 
Carretero Zamora, Juan Manuel (2016): Gobernar es gastar: Carlos V, el servicio de las Cortes de Castilla y la deuda de la Monarquía Hispánica, 1516-1556, Madrid, Sílex.

Colmeiro, Manuel (1883): Cortes de los antiguos reinos de León y Castilla, «Introducción», parte primeira, Madrid, Sucesores de Rivadeneyra.

Danvila y Collado, Manuel (1899): Historia crítica y documentada de las Comunidades de Castilla, Madrid, Viuda e Hijos de M. Tello.

Dios, Salustiano de (1991): «El funcionamiento interno de las Cortes de Castilla durante los siglos XVI y XVII: las ordenanzas de votar (primera parte)», Revista de las Cortes Generales, 24, 185-274.

Dios, Salustiano de (1992): «El funcionamiento interno de las Cortes de Castilla durante los siglos XVI y XVII: las ordenanzas de votar (segunda parte)», Revista de las Cortes Generales, 25, 133-215.

Domínguez Ortiz, Antonio (1961): «Concesiones de votos en Cortes a ciudades castellanas en el siglo XVII», Anuario de Historia del Derecho Español, XXXI, 175-186.

Eiras Roel, Antonio (1995a): «Las Juntas del Reino de Galicia: orígenes y proceso de institucionalización», Obradoiro de Historia Moderna, 4, 115-182.

Eiras Roel, Antonio (1995b): «Las Juntas del Reino de Galicia en el período protoinstitucional, 1599-1629», en Actas de las Juntas del Reino de Galicia, I, Santiago de Compostela, Xunta de Galicia, 1-45.

Fernández Albaladejo, Pablo (1992): Fragmentos de Monarquía, Madrid, Alianza Editorial.

Fernández Cortizo, Camilo (2012): «Población rural, mundo urbano y migraciones», en Isidro Dubert (coord.), Historia de la Galicia moderna: siglos XVI-XIX, Santiago de Compostela, Universidade, 39-93.

Fernández Duro, Cesáreo (1883): Memorias históricas de la ciudad de Zamora, su provincia y obispado, t. IV, Madrid, Sucesores de Rivadeneyra. 
Fernández Vega, Laura (1980): «Las Juntas del Reino de Galicia y la recuperación del voto en Cortes», Compostellanum, XXV:1-4, 68-118.

Fernández Vega, Laura (1982): La Real Audiencia de Galicia: órgano de gobierno del Antiguo Régimen, A Coruña, Deputación.

FERNÁNDEZ VEGA, Laura (1995): «Orígenes y antecedentes, naturaleza y función de las Juntas del Reino de Galicia, hasta la recuperación del voto en Cortes», en Antonio Eiras Roel (coord.), Actas de las Juntas del Reino de Galicia, I, Santiago de Compostela, Xunta de Galicia, 53-80.

Fernández-Villamil, Enrique (1952): La escuadra de Galicia, Pontevedra, Casa Julio Antúñez.

Fernández-Villamil, Enrique (1962): Juntas del Reino de Galicia, Madrid, Instituto de Estudios Políticos.

Feros, Antonio (2002): El duque de Lerma: realeza y privanza en la España de Felipe III, Madrid, Marcial Pons.

García Oro, José (1977): Galicia en la Baja Edad Media, Santiago de Compostela, El Eco Franciscano.

García Oro, José (1987): Galicia en los siglos XIV y XV, A Coruña, Fundación Pedro Barrié de la Maza, Conde de Fenosa.

García Oro, José (1994): Don Fernando de Andrade, conde de Villalba (1477-1540), Santiago de Compostela, Xunta de Galicia.

García Oro, José (2000): «La nobleza gallega en el reinado de Carlos V», en Antonio Eiras Roel (coord.), El Reino de Galicia en la época del Emperador Carlos V, Santiago de Compostela, Xunta de Galicia, 99-134.

LADERo QuesadA, Miguel Ángel (2005): La Hermandad de Castilla: cuentas y memoriales, 1480-1498, Madrid, Real Academia de la Historia. 
López DíAz, María (2006): «Municipio y reforma: Ourense, otro ejemplo del fracaso de la política reformista borbónica», Cuadernos Feijonianos de Historia Moderna, III, 133-181.

Lorenzana de la Puente, Felipe (2014): La representación politica en el Antiguo Régimen: las Cortes de Castilla, 1655-1834, Madrid, Congreso de los Diputados.

Mariana, Juan de (1989): La dignidad real y la educación del rey (De rege et regis institutione). [Edición de Luis Sánchez Agesta]. Madrid, Centro de Estudios Políticos y Constitucionales.

Martín, José Luis (1999): Las Cortes Medievales, Madrid, Historia 16.

Olivera Serrano, César (1986): Las Cortes de Castilla y León y la crisis del Reino (1445-1474): el Registro de Cortes, Burgos, Cortes de Castilla y León.

Olivera Serrano, César (1989): «La ausencia de Galicia en las Cortes del siglo XV», El Museo de Pontevedra, 43, 315-322.

Pardo de Guevara y Valdés, Eduardo (1997): Don Pedro Fernández de Castro, VII conde de Lemos (1576-1622), Santiago de Compostela, Xunta de Galicia.

Pardo de Guevara y Valdés, Eduardo (2006): «A pacificación de Galicia polos Reis Católicos: “O feito que Zurita chamou a 'doma e castración' do Reino de Galicia...”», en Francisco Singul (dir.), Os Capítulos da Irmandade: peregrinación e conflito social na Galicia do século xv, Santiago de Compostela, Xunta de Galicia, 438-465.

PÉREZ, Joseph (1977): La revolución de las Comunidades de Castilla (1520-1521), Madrid, Siglo XXI.

Piskorski, Wladimiro (1933): Las Cortes de Castilla en el periodo de tránsito de la Edad Media a la Moderna, 1188-1520, Barcelona, Universidad.

Rubio Martínez, Amparo (2016): El reinado de los Reyes Católicos en Galicia: actividad económica y fiscalidad regia, Santiago de Compostela, CSIC. 
SaAvedra Fernández, Pegerto (2007): «A Galicia do Antigo réxime (ca. 1480-ca. 1835): política e cultura», en Xosé Ramón Barreiro Fernández / Ramón Villares Paz (coords.), A gran historia de Galicia, VIII, vol. I, A Coruña, La Voz de Galicia.

SaAvedra Fernández, Pegerto (2013): Demarcacións, topónimos, papeis, memoria: sobre a división e o control do territorio na Galicia moderna, A Coruña, Real Academia Galega.

Sandoval, Prudencio de (1846): Historia del emperador Carlos V, Madrid, Tipografía de P. Madoz y L. Sagasti.

Silva Ferreiro, Manuel (1925): Galicia, voto en Cortes: ensayo de investigación histórica, Santiago, Tipografía del Seminario.

Thompson, Irving A. A. (1989): «Cortes y ciudades: tipología de los procuradores (extracción social, representatividad)», en AA. VV., Las Cortes de Castilla y León en la Edad Moderna, Valladolid, Cortes de Castilla y León.

Triano Milán, José Manuel (2018): La llamada del rey y el auxilio del reino: del pedido regio a las contribuciones de la Santa Hermandad (1406-1498), Sevilla, Universidad.

Vales Villamarín, Francisco (2006): Obra completa: aproximación a la historia de Betanzos y su comarca, Betanzos, Briga. 



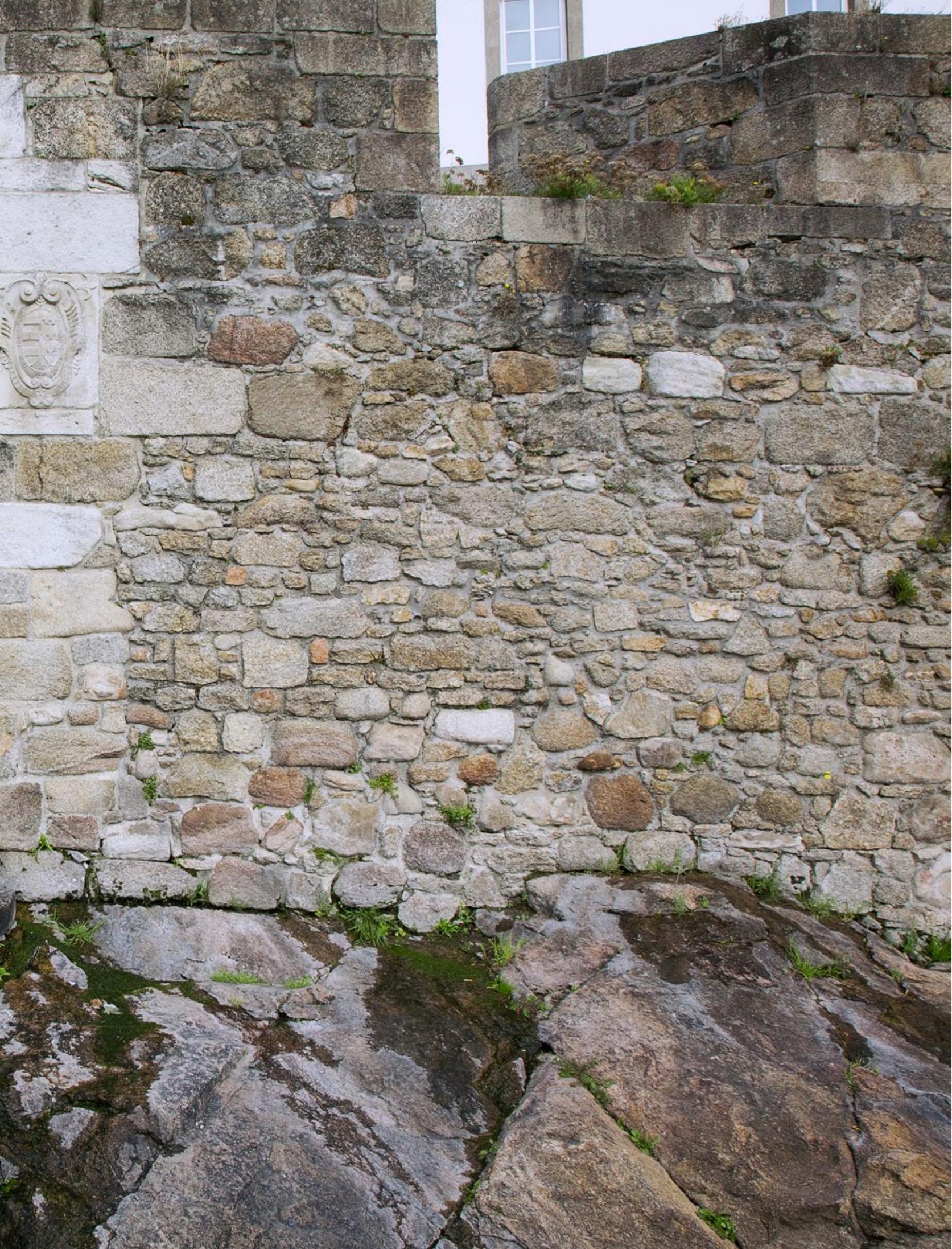

